\title{
The Analysis of Classroom Interaction in English Class using Foreign Language Interaction
}

\author{
Kesmila Indung Putri ${ }^{1}$, Hilma Pami Putri ${ }^{2}$ \\ ${ }^{1}$ State Islamic Institut of Bukittinggi (IAIN) Bukittinggi, e-mail : ikes.putri02@gmail.com \\ 2 State Islamic Institut of Bukittinggi (LAIN) Bukittinggi, e-mail:mrsbentama@gmail.com
}

\begin{abstract}
(i) (2)
(C)2021 by the authors. Submitted for possible open access publication under the terms and conditions of the Creative Commons Attribution-ShareAlike 4.0 International License-(CC-BY-SA) (https://creativecommons.org/licenses/by-sa/4.0/)
\end{abstract}

d. DOI: bttps://10.30983/mj.v1i1.5117

Submission: August 02, 2021

Revised: November 20, 2021

Published: December 31, 2021

\begin{abstract}
Abstrak
Pengelolaan interaksi kelas selama proses belajar mengajar di kelas sangat penting untuk mencapai tujuan pembelajaran bahasa Inggris. Studi pendahuluan menunjukean babwa guru masih mendominasi saat berbicara di ruang kelas dibanding para siswa. Tujuan dari penelitian ini adalah untuk menemukan alasan teacher talk masih mendominan dari pada student talk dan untuk mengetabui kategori yang dominat digunakan dikelas berdasarkan kategori FLINT. Desain penelitian ini adalah kualitatif deskriptif. Data didapatkan melalui observasi dan interview. Data dianalisis dengan cara menadopsi sistem kategori FLINT (Classroom Interaction, Foreign Language Interaction). Informan dari penelitian ini adalah guru bahasa Inggris dan para siswa di kelas sepuluh jurusan Otomatisasi dan Tata Kelola Perkantoran (Office Automation and Governance) di Sekolah Menengah Kejuruan Negeri (SMKN 2) Bukittinggi. Temuan penelitian ini menunjuk.kan babwa teacher talk lebih dominant daripada student talk karena respon dan inisiatif siswa rendah. Siswa berbicara apabila guru mendorong dan menyuruh siswa untuk berbicara, siswa malu unyuk. berbicara menggunakan bahasa Inggris dan siswa takut untuk. membuat kesalahan. Kategori yang dominant digunakan guru dalam teacher talk selama aktivitas belajar menagajar di ruang kelas berdasarkan sistem kategori FLINT adalah memberi informasi, memberi arahan, dan memberi pertanyaan. Disimpulkan babwa teacher talk mendominasi bentuk. interaksi di ruang kelas. Babkan, meskipun guru telah melibatkan siswa selama proses belajar mengajar, namun sebagian siswa masih bersikeap secara pasif di dalam kelas.
\end{abstract}

Keywords: interaksi kelas, FLINT kategori sistem, teacher talk, student talk.

\begin{abstract}
The classroom interaction management during the teaching and learning process in the classroom is very important to achieve the objectives of learning English. Nevertheless, the preliminary studies indicated that teachers dominate when speaking in the classroom rather than students do. Therefore, the purpose of this research is to find out the reason of English teacher talk is more dominant than students talk and the category which is dominantly used in class based on the FLINT category. The design of this research is descriptive qualitative. The data collected through observation and interviews. FLINT (Classroom Interaction, Foreign Language Interaction) category system was used to analyze the data. The English teacher and students in the tenth grade majoring in Office Automation and Governance (OAG) at State Vocational School (SMKN 2) Bukittinggi became the informants of the study. It was found that teacher talk was more dominant than students talk because of low student response and initiative. The students speak when the teacher encouraged and got them use the target language. They were being ashamed and afraid to make mistakes in using the target language. The dominant categories which were found in teacher talk during the teaching and learning process according to the FLINT category system were giving information, giving directions, and asking questions. It was concluded that it was teacher talk dominated the interaction in the classroom. In fact, even though the teacher has involved students during the teaching and learning process, some students were still passive in the classroom.
\end{abstract}

Kata Kunci: classroom interaction, FLINT system analysis, teacher talk, student talk 


\section{Introduction}

Interaction is the fondation of second language learning, in which learners are involved in both improving their own communicative abilities and social skills (Brown, 2000 : 165). Teaching and learning second language in the classroom should be conducted as an interaction to get language models and facilities. Huriyah (2018 : 61) states that interaction is one essential point of prosperous in teaching learning process, because interaction is a united exchange of thought, feeling or ideas between a teacher and learner or a learner and other learner consequesnt in complementary effect on each other. In the classroom, both teacher and students should have the willingness to participate in the interaction. Interaction between teacher and students as well as student and student is required in classroom activities.

Pistarman (2015) states that classroom interaction in English classes happens by using English. The students and teacher sometime use bilingual or use fifty-fifty English, which means the teacher sometimes translate their English to their mother tongue. In the English class, teacher and students at least speak English 50\% of the time in the classroom. If the students do not understand the meaning of the word, the teacher can translate the word into Bahasa Indonesia. The students can mix their language with Bahasa when they do not know how to say the word in English language. When interaction has a high quality, it is very possible that the process of affective and efficient English teaching and learning will appear. Though interaction, students can increase their language mastery during teaching and learning process, either directly or indirectly. Irwandi $(2018: 42)$ states that that learning second language involves complex activity and need the learners' curiosity to reach the learning goals.

Bestiara (2021 : 2) states that the ability to explain material the teacher must use clear langauge and the key point must be clearly express while teaching and learning process. In other words, classroom interaction can described as the communication of the teacher and students in the classroom. Classroom interaction occurs between the teacher and the students and the teacher plays an important role as communicator, informant, and model for students.

Puji (2018) states that classroom interaction is an essential part of teaching and learning process whereby two or more people communicate verbally or nonverbally. Verbal interaction takes place when of the teacher and the students talk, while non verbal interaction covers gestures of facial expression by the teacher and students when they communicate without using words. Classroom interaction becomes an important feature of teaching and learning process. Through classroom interaction, the teacher can encourage the students to speak, think, and give responses. Arima(2020 : 4) says that non-verbal communication is not only about communicating, but also expressing emotional and feeling that have meaning and purpose. Non verbal communication is important because it gives the teacher valueble information about situation in the classroom. Sharliz (2017 : 3) explains that classroom interaction occurs not only in the classroom and at the school but also anywhere the teaching leaning process occurs. This definition shows that classroom interaction occurs in the classroom activities and the teacher plays an important role as the class organizer. As a result, interaction does not occur solely from one side, mutual impact through the exchange of signals is required to create communication.Classroom interaction is important in teaching and learning process because it can help teacher to develop material and potential of the students, as well as help students understand more about the material. Ani (2017 : 16) states that interactions are defined as the 
learners' engagement with the course, other learners, the instructor and the technological medium used in the course.

M.G.Moree (1989) proposes there types of interaction in mind, those are interaction between teacher-student, interaction between student-student, and interaction between student-content. Teacher and students interaction are process of interaction between a teacher and students during the teaching and learning process. Interaction can help teachers to communicate with the students easily and teachers can learn the weaknesses and qualities of the students in their class. According to Kardena (2017 : 64) that English teacher should work collaboratively with the students. In other words, both the teacher and the students have their own contributions in building students' communiction ability. A teacher has role as a guide, facilitator, expert or support person depending on situation. Teacher should achieve a match between teaching strategies and the students uniques styles to improve students learning result (Agus, 2020; Hani\&Lismay: 2020 : 85). The interaction between student-student. Student-student interaction is student communication in a classroom with other students in a group in teaching and learning process. Student-to-student interaction builds communication skills in class, which supports productive and satisfying learning and helps students develop problem-solving and critical thinking skills. The interaction between student-content is well recognized as a type of interaction. This kind of interaction occurs when the students engage in active reading and writing.

Meanwhile, Dagarin as citied in Margana (2019 : 129) proposes four types of classroom interaction. (1)Teacher - Learner. This interaction is established when a teacher talks to the whole class of students in the classroom. Teacher has role as classroom leader and decides what activity the students will do at the time. (2) Teacher - Learner / a Group of Learner. It occurs when the teacher refers to the whole class but expects only certain students to answers the teacher' questions. This interaction is used to check the students' understanding about the lesson. (3) Learner - Learner. This interaction occurs when the students got an assignment from the teacher and they had to do it in pairs. After the students finish their task, they will present their task in the classroom to whole students. (4) Learner-Learners. This interaction is conducted when the students have a task to do in the form of groups. For instance, after the students work in pairs, the teacher puts the pairs into a whole group. The pairs compare and present their task in the classroom.

Classroom based research has produced a variety of models that operate from a variety of perspectives to describe and analyze classroom interaction. The method of 'interaction analysis' is based on Flanders' description categories of verbal action in the classroom. The tools which can be used to analyze classroom interaction are Foreign language Interaction (FLINT), Flanders' Interaction Categories (FIAC), and Brown Interaction Analysis System (BIAS). In this research, the researcher used Foreign Language Interaction (FLINT). Brown (2001) states that Foreign Language Interaction System is one of the guidelines toanalyze the interaction activities and this analysis system has several benefits. It is helpful in developing interactive language teaching since it gives the teacher a taxonomy for observing the others

teachers, set a framework for evaluating and improving the teaching and helps to set a learning climate for interactive teaching. This is an interaction analysis which is applicable for classroom observation. 
Brown adaptes some categories from the obsevation of classes taken by Flanders and Morkowitz and the FLINT model with several adaptations and additions by Brown to make the categories more relevant and suitable to practice in the language classroom. Brown (2001 : 168) divides this model focus on the teacher talk and student talk. FLINT also divides teacher talk into direct and indirect influence to know whether the teacher is more direct or indirect in teaching students. The categories of teacher talk which are included in indirect influence relate to feelings, praises or encourage, jokes, the use of students' idea, repeat students' responses in verbal, and ask questions. Another influence in the teacher talk is direct influence which is done whose aim is to encourage students to involve directly in teaching and learning activity, such as: giving information, correcting without rejection, giving direction, and criticizing students behaviour. Student talk can be used by the students to express their own ideas, initiate new topics, and develop their own opinions.

Based on the preliminary observation that was conducted on September 8th 2020 in SMK N 2 Bukittinggi, the researcher found some problems. The researcher came to the class X-OTKP 1 during the English language teaching and learning process and saw that the teacher talk was still dominant than the students talk. During the classroom observation, the researcher saw that most of the students were still afraid to talk because they were afraid to make mistakes and did not confident to speaking English. They spoke by using Bahasa Indonesia and they were shy to speak English. Some of the

students were quieter bacause they thought learning English was difficult. Some of the students seemed not intersted in learning English. It can be seen by their passive participation in English class. The students just silent and had difficulties to answer the teacher' question in English language because they lacked of vocabulary.

The teacher talk was still dominant in that class. The students participated in talking when the teacher encouraged and asked them to talk. When the teacher directed one student to answer a question, she/he did not answer the question. If the teacher asked all of the students in the class to answer, some of them answered the question together but when the teacher pointed one student to answer again, they were silent. After the teacher finished explaining the material, the teacher asked the students " Do you understand?" and the students said "Yes Mr". And then the teacher asked again if they had any question and the students said "No Mr".

The teacher have tried to improve interaction in the classroom. The teacher has tried to make the students active in the class by encouraging the students, asking them to speak, asking them some questions. The teacher has also involved students in the learning process, such as asking students to make answers on the whiteboard, asking students to correc their friends' incorrect answers and asking students to read aloud the correct answer. However, some of the students were still less active when learning process took place and were silence when the teacher asked them to answer a questions. Based on the observations that the researcher done, the researcher saw that the interaction class was still low.

\section{Method}

The design of this research was descriptive qualitative. Descriptive qualitative research involves analyzing, describing and summarizing various condition, situation and various data collected in the form of interview or observations regarding the problems studied that occur in 
the field. The researcher observed the interaction of teacher and students during teaching and learning process. Foreign Language Interaction (FLINT) Analysis System was used to get the data. Through FLINT Analysis System, researcher described the result of the research by showing the phenomena that occur in the classroom, such as aspects of students and teacher during classroom interaction. The informants of this research were an English teacher and students of the tenth grade at SMKN 2 Bukittinggi.

The observation sheet and interview question were used as the instrument of the research. Observation sheet was used to note any important things that appeared and related to FLINT system categories. The data were analyzed by adopting Foreign Language Interaction (FLINT) System Categories. The researcher observed the classroom interaction in the class and also interviewed an English teacher and students about the interaction in the classroom.

The data analysis technique in this study used Miles and Hubermans' theory (2014) encompassing data reduction, data display and conclusion. On the data reduction, the researcher transcribed the row data into the written form after conducting observation and interview. The findings were concluded by rechecking the data and narrated as a report of the research.

\section{Results and Discussion}

The researcher came to the classroom and observed the classroom interaction that happened in the class. The researcher brought the observation sheet and checked the items based on the situation that happened in the classroom. During observation, the researcher used an observation checklist and an observation sheet to help researcher to observe situation in the classroom. The result of having observation in the classroom was not all of the FLINT categories were applied in the classroom.

\section{1) Teacher talk}

Foreign Language Interaction Analysis ( FLINT) System describes the teaching and learning process according to the classroom language for teacher talk. The categories of teacher talk are divided into two kinds of talk: indirect influence and direct influence.

a. Dealing with Feelings

Dealing with feelings is in a no threatening way, accepting, discussing, referring to, or communication understanding of past, present or future feelings of students. In this category, teacher communicated with the students and asked their feeling beginning the teaching and learning activity. The teacher also made sure students' condition before starting the lesson. For example:

Extract 1

\begin{tabular}{|cc|}
\hline Teacher & $\begin{array}{c}\text { Good } \\
\text { students.... }\end{array}$ \\
\hline Students & Good morning sir.... \\
\hline Teacher & How are you today? \\
\hline Students & $\begin{array}{c}\text { I am fine. Thank you. } \\
\text { How about you ? }\end{array}$ \\
\hline Teacher & I am good. Thank you \\
\hline
\end{tabular}

After making sure the students' condition, the teacher took students' attendance list. If the teacher ask students like " how are you today?" and sometimes the students just kept silent or 
laughed, the teacher encouraged them to answer. The teacher said "you can say I am fine, I am great and so on." Then, the teacher got the students to say it.

Based on the observation the researcher can conclude that the teacher used the first category of FLINT system. The category is deals with feelings. The teacher tended to uses this category before and during the teaching and learning process.

b. Praising or Encouraging

The overall praises or encourages is praising, complimenting, telling students why what they have said or done is valued. Encouraging students to continue, trying to give them confidence, confirming that answers are correct. The teacher gave praise and encourage to the students during the class interaction. In addition, praising and encouraging will help them to be more confident when they speak. Based on the observation, the teacher praised and encouraged the students. For instance:

Extract 2

\begin{tabular}{|cc|}
\hline Teacher & $\begin{array}{c}\text { OK.... Who next? You have got six } \\
\text { sentences. So choose one of the } \\
\text { sentences. Pilih satu,,, come on.... }\end{array}$ \\
\hline Student & (rise his hand and make the correct \\
& answer in the whiteboard) \\
\hline Teacher & OK..... Good ... Thank you. (give \\
& $\begin{array}{c}\text { applause) } \\
\text { Coba baca. Baca yang kamu tulis. (Try } \\
\text { to read it. Read what you wrote). }\end{array}$ \\
\hline Student & Will you enjoy the sunset? \\
\hline Teacher & OK... have a sit please \\
\hline
\end{tabular}

It shows that the teacher encouraged the students who answered the question correctly and initiated to answer it shortly. By encouraging and praising them, the teacher could make the students become more confident to answer the teacher's questions.

Praising and encouraging the students can arise positive effect to students, lead them to have self-confidence to speak, and make them to be active during teaching and learning process. This category is important as well as it can create a harmonious relationship between teacher and students.

\section{c. Joking}

The teacher made a joke, kidding, and puns during teaching and learning in the classroom as displayed in the table below:

Extract 3

\begin{tabular}{|lc|}
\hline Teacher & $\begin{array}{c}\text { Okay. the first is wake up. Next... } \\
\text { apalagi? (What is next?) }\end{array}$ \\
\hline Students & Clean up \\
\hline Teacher & OK.. next?? \\
\hline Students & Take a bath \\
\hline Teacher & $\begin{array}{c}\text { Good. Take a bath. How many } \\
\text { times do you take a bath every day? }\end{array}$ \\
\hline Student 1 & There \\
\hline
\end{tabular}




\begin{tabular}{|c|c|}
\hline Students & Laughing \\
\hline Student 2 & Two.. \\
\hline Teacher & $\begin{array}{l}\text { Twice ya... so, you take a bath } \\
\text { twice a day. Take a bath } \\
\text { Takabe ya.... }\end{array}$ \\
\hline Students: & Laughing \\
\hline
\end{tabular}

The transcription above shows that in the classroom activities sometimes the teacher makes humor and something to create a fun situation. This is aimed to make the students are enjoyable during the teaching and learning process. The teacher joked to make classroom' atmosphere not under pressure. Besides, the teacher promoted a more friendly relationship with the students.

d. Using idea of the students

The overall using ideas from the students are clarifying, using, interpreting and summarizing the ideas of students. Teacher can use students' ideas to summarizing the lesson or to answer a question. Based on the data that has been found by the researcher in the classroom observation, it was found that the teacher used the students' idea after asking them as seem below:

Extract 4

\begin{tabular}{|cc|}
\hline Student & I have breakfast in the morning \\
\hline Teacher & $\begin{array}{l}\text { Ya.. I have breakfast in the } \\
\text { morning, mana yang menjadi verbnya } \\
\text { (Which one is verb?) }\end{array}$ \\
\hline Student & Have ... \\
\hline Teacher & $\begin{array}{l}\text { Kalau ditambah where, bagaimana } \\
\text { jadinya (If you add "where", what is } \\
\text { the form of the sentence?) }\end{array}$ \\
\hline Student & $\begin{array}{l}\text { Where do you have breakfast with } \\
\text { your family? }\end{array}$ \\
\hline Teacher & OK... Write it on the whiteboard. \\
\hline
\end{tabular}

Based on the conversation, the teacher made clarification based on the students' explanation about their argument. After listening to the students' explanation, the teacher clarified and summarized it into a sentence. It is assumed that the teacher tried to get idea from the students and make the students active in the class.

e. Repeating student responses verbatim

The overall of repeats student responses verbatim is repeat the exact words of students after they participate.

Extract 5

\begin{tabular}{|l} 
Teacher \\
\\
\\
(There's a verb that's been missed, \\
right?) forget...? What does it mean \\
by forget?
\end{tabular}




\begin{tabular}{|cc|}
\hline Students & Lupa...(Forget..) \\
\hline Tecaher & $\begin{array}{c}\text { Lupa... (Forget..). Do you forget to } \\
\text { bring an umbrella to school }\end{array}$ \\
\hline Students & Yes \\
\hline Teacher & $\begin{array}{l}\text { Why do you bring an umbrella to } \\
\text { school? }\end{array}$ \\
\hline Student & Rain \\
\hline Teacher & Yeah.. Because it rain. Good \\
\hline
\end{tabular}

The teacher repeated word after the students said the word. The teacher tried to get idea from the students, get the students to be active. The teacher also repeated the word or the answer of the students.

\section{f. Asking question}

The overall of ask question is questions to which the answer is anticipated. The teacher asked the students to check their understanding related to the material.

Extract 6

\begin{tabular}{|c|c|}
\hline Teacher & $\begin{array}{l}\text { Get breakfast.... Setelah ini apa } \\
\text { lagi? (What's next after this?) }\end{array}$ \\
\hline Student & Sholat (pray). \\
\hline Teacher & $\begin{array}{l}\text { Pray subuh and get breakfast. } \\
\text { OK, in the afternoon we can say... get } \\
\text { lunch. In the evening? We can say?? } \\
\text { How to say to get some food in the } \\
\text { evening? }\end{array}$ \\
\hline Students & (silent) \\
\hline Teacher & $\begin{array}{l}\text { Apa namanya kalau makan malam } \\
\text { dalam bahasa Inggris? (What do you } \\
\text { say makan malam in English?) }\end{array}$ \\
\hline Student & Dinner \\
\hline
\end{tabular}

In asking a question, the teacher frequently asked the students about their understanding related to the materials and direction given by asking "Do you Understand?". The teacher explain the material, after explaining and directing the material the teacher asked question to the students "Do you get the point?". Asking question is the best way to encourages students' participation in teaching and learning process. Although asking the students using those expression are less appropriate since they only need simple responses and polar answers, just by saying yes or no. Based on the data above, the researcher found that the teacher used the sixth category of FLINT system. The category is asks questions.

g. Giving information

Giving information happened when teacher was explaining something related to the learning material and then the teacher give some question to the students. The students answer the question in the wrong answer and then the teacher repair the answer and give the correct answer. The teacher used Indonesian language to explain the answer and information to the students. Giving information involves giving the students information, fact and the teacher's own opinion.

Extract 7 


\begin{tabular}{|ll|}
\hline Teacher & i am going to enjoy... jadi ini boleh langsung \\
& kepada object. Boleh juga dibatasi oleh kata kerja. \\
& Jadi dua kata kerja harus dibatasi dengan to ya... \\
& kalau dia kata kerja di sambut kata kerja, maka kata \\
& kerjanya bentuk.. \\
\hline Student & Pertama \\
\hline Teacher & bentuk pertama. Apa contohnya. Saya akan menghadapi ujian. \\
& I am going to .... \\
\hline Students & silence \\
\hline Teacher & I am going to get final examination. Kalau dia \\
& $\begin{array}{l}\text { disambut kata kerja, maka dia harus kata kerja } \\
\text { bentuk pertama. Tapi kalau dia bukan kata kerja, }\end{array}$ \\
& maka kita bisa memasukkan tobe..... saya akan \\
bahagia. I am going to be happy.. \\
\hline
\end{tabular}

h. Correcting without rejection

Correcting without rejecting is telling students who have made a mistake without using word or intonations which communicate criticism. The teacher corrected the students answer without rejection. The teacher also repeated the students' answer and sometimes the teacher ask the students to write the answer in the whiteboard.

Extract 8

\begin{tabular}{|cc|}
\hline Teacher & Kalau breakfast sarapan. Kalau in the afternoon? \\
\hline Students & Silence \\
\hline Teacher & $\begin{array}{c}\text { get lunch. Kalau untuk makan malam apa bahasa } \\
\text { inggrisnya? }\end{array}$ \\
\hline Students & Dinner \\
\hline Teacher & $\underline{\text { Ya.. Dinner. }}$ \\
\hline
\end{tabular}

i. Giving direction

The overall giving direction encompassing giving directions and commands that students are expected to follow; directing various drills, and facilitating whole class and small group activity. Teacher directed the students through the various exercises and facilitated them by giving a whole-class or small-group activities. Teacher gave direction to the students when the teacher wants the students to do something.

Extract 9

\begin{tabular}{|ll|}
\hline Teacher & $\begin{array}{c}\text { (Explain the pattern of simple present } \\
\text { and ask the students to write the example) }\end{array}$ \\
& $\frac{\text { you... please make one example }}{\text { menggunakan rumus yang didepan. }}$ \\
\hline Make the example in the whiteboard
\end{tabular}

The category of giving direction is commonly applied when the teacher acts as a director which directs the students in the classroom. When the teacher conducted an activities in the class, 
the teacher give direction to the students so that the students are not clueless to express their own ideas.

j. Criticizing students behavior

Criticizing students' behavior is rejecting the students' behavior, trying to change the nonacceptable behavior, communicating anger, displeasure, annoyance, and dissatisfaction. According to Talis (2009) Teachers' belief about teaching is a quite classroom which generally needed for effective learning. Teacher should know the way to communicate the emotion atmosphere in the classroom so teacher can find a solution to solve the problem and build a positive interaction with students. Telling students about incorrect or acceptable response must be done in positive behavior without letting down the students' passion in learning.

Extract 10

\begin{tabular}{|ll|}
\hline Teacher & (Teacher explaining the material) \\
\hline Student & (talking with their friend and langhing) \\
\hline Teacher & $\begin{array}{l}\text { You.... now make an example of } \\
\text { simple past tanse in the whiteboard and } \\
\text { garis bawahi subject, verb nya dan lain } \\
\text { lain. } \\
\text { Student }\end{array}$ \\
Teacher & $\begin{array}{l}\text { (maju dan bingung di depan papan } \\
\text { Makanya lain kali, kalau guru } \\
\text { menjelaskan you perhatikan jangan } \\
\text { ngobrol.... }\end{array}$ \\
&
\end{tabular}

In criticizing student behavior, most of the teacher's utterances were intended to manage the classroom, keep the students' attention, and listening to the teacher at the time.

\section{2) Student Talk}

Foreign Language Interaction Analysis ( FLINT) System describes the teaching and learning process according to the classroom language for students talk.

a. Students' Specific Response

Students' Specific Response occurred when the teacher gave commands were expected to follow and the students answered specific response from the specific question that asked by the teacher. Students' specific response refers to their response to the teacher within a specific and limited range of available or previously practiced answers.

Extract 11

\begin{tabular}{|cc|}
\hline Teacher & Kamu bisa membedakan dialog / monolog. \\
& Text itu ada dua. Monolog artinya sendiri. Dialog \\
& ada terjadi pembicaraan antara dua atau lebih \\
& yaa... so dialog between budi and amir. So this \\
& is dialog or monolog? \\
\hline Students & Dialog...... \\
\hline Teacher & Dialog.. okay \\
\hline
\end{tabular}


b. Students' response, open ended or student-initiated

The second category of students talk is students' response, open - ended or student-initiated. The overall of students' response, open - ended or student-initiated is responding to the teacher with students' own ideas, opinions, reactions, feelings. Giving none from among many possible answers that have been previously practiced but from which students must know make a selection. Students are freely to ask and express anything on their mind to teacher.

Extract 12

\begin{tabular}{|cc|}
\hline Teacher & $\begin{array}{c}\text { Okay.. now we change in to negative. } \\
\text { Kita ubah jadi negative dulu. I am not... } \\
\text { change into negative. Come on..... i not going }\end{array}$ \\
\hline Students & $\underline{\text { I am not going to go to bali }}$ \\
\hline Teacher & Okay. Nextyou \\
\hline Students & $\underline{\boldsymbol{I} \text { am } \text { not going to enjoy the }}$ \\
\hline Teacher & Okay.. good \\
\hline
\end{tabular}

c. Silence

Silence is a pause in the interaction. This is a period of quiet during which there is no verbal interaction.

Extract 13

\begin{tabular}{|cc|}
\hline Teacher & jadi di sini, will di sini menyatanyakan sebuah \\
& $\begin{array}{l}\text { rencana yang belum terjadi dan akan dilaksanakan } \\
\text { atau akan di eksekusi. Do you understand ? it is } \\
\text { clear? }\end{array}$ \\
\hline Students & Yes,, \\
\hline Teacher & soo... what is the different between will and be \\
& going to? Apa bedanya? \\
\hline Students & Silent.
\end{tabular}

The reason the teacher talk was dominant over the student talk since the students' response is too low. Moreover, the teacher also involves the students in teaching and learning process. Sofyan (2013 : 46-47) states that the understanding from teacher and the right way of handling with students feeling will comfort the teacher-students interaction in the classroom.

Sometimes, the teacher makes the students enjoy the learning by inserting jokes, such as making jokes about the material of the day or games such as vocabulary games. The teacher often tries to make the students speak English in the classroom. When the teacher gives an assignment, sometimes the teacher checks students' assignments one by one. Therefore, the teacher assigned one of the students to make the answer and then asked the student to read what she/he wrote. The teacher also gave reinforcement about students' answer. When the teacher asked the students' ideas, the teacher gave reinforcement, feedback and concluded the ideas to make the students more understand. 
Besides, the dominant categories of classroom interaction that are used in the teaching and learning English language based on FLINT categories system are giving information, giving direction and asking question. When delivering information to the students, the teacher sometimes used Bahasa Indonesia to help them understanding the materials and avoid misunderstandings. Using Bahasa Indonesia is helpful for the students understanding the information delivered by the teacher. Moreover, the teacher checks the students' talks.

The teacher sometimes give directions at the end of the lesson and in the middle of learning. For example, the teacher asked the students to make the answer on the whiteboard, asked the students to read text that given by the teacher, asked the students to read aloud, asked students to make their tasks, asked the students to make their homework, and so on. During the observation, the researcher saw that students always responded and did what the teacher got them to do. This category is commonly applied when the teacher acts as a director which directs the students in doing group work activity.

In asking question, the teacher frequently asks the students to check their understanding on the materials, and lead them becoming active learner during learning activity. If the class is silent, the teacher repeats the question, and even translates it into Bahasa Indonesia.

\section{Conclusion}

The teacher talk was still dominant than the student talk because student response specific and students response open ended or student-initiated are low. The dominant categories of classroom interaction that happened in the class based on the FLINT categories system are giving information, giving direction and asking questions. These categories are used by the teacher in the classroom The teacher occasionally used Babasa Indonesia when delivering information which aims at helping to understand about material and to avoid misunderstanding.

\section{References}

Ani. (2017). The Analysis of Young Learners' Classroom Interaction At an English Course English Education Department Tarbiyah and State Islamic University.

Arima, S. (n.d.). Ellite Journal of Education, Linguistics, Literature and Language Teaching Students Perception on the Teacher's Nonverbal Communication at the Seventh Grade Students of MTSS Nagari Binjai Pasaman.

Astutie, S. (2020). An Analysis of Teacher Talk and Student Talk in English Classroom Interaction Using FLINT System at The Ninth Grade of SMP Negeri 3 Hulu Sungai Tengah (Vol. 2, Issue 2).

Brown, H. D. (2007). Principles of language learning and teaching. Pearson Longman.

Dagarin, M. (2004). Classroom Interaction and Communication Strategies in Learning English as a Foreign Language. ELOPE: English Language Overseas Perspectives and Enquiries, 1(1-2), 127-139. https://doi.org/10.4312/elope.1.1-2.127-139 
Delona Pratiwi, F. (n.d.). ELLITE Journal of Education, Linguistics, Literature and Language Teaching Hani, U., \& Lismay, L. (2020). The learning style of Millenial Students at English Education Department of IAIN Bukittinggi. The Journal of English Literacy Education, 7(2), 84-91.

Hoerun Nisa, S. (2014). Classroom Interaction Analysis In Indonesian EFL Speaking Class. In English Review: Journal of English Education (Vol. 2, Issue 2). http://journal.uniku.ac.id/index.php/ERJEE

Huriyah, S., \& Agustiani, M. (2018). An Analysis of English Teacher and Learner Talk in the Classroom Interaction. Linguistic, English Education and Art (LEEA) Journal, 2(1), 60-71. https://doi.org/10.31539/leea.v2i1.385

Irwandi, Quidy, G. \& Albert. (2018). Teaching Vocabulary in Contextualization for Young Learners. ICOELT-6.

Kardena, A. (2017). Teacher's Role as An Information Gatherer: A Hidden Part in Developing Learning in Context.

Kartika, R., \& Winarti, D. (n.d.). Classroom Interaction in the Teaching Of Speaking for the Eighth Graders at MTS Surya Buana Malang.

Lismay, 1. (2021). The students' perception of teachers' basic teaching skills in the english classroom. Of english language pedagogy, 6(2), 1-9.

Pratama, B., Lubuklinggau, S.-P., \& Triyogo, A. (n.d.). An analysis of classroom interaction in english teaching and learning process at eighth grade students of smp it annida lubuklinggau.

Rayhana Sofyan Murni Mahmud, R. (n.d.). Teacher Talk in Classroom Interaction: A Study at an English Department in Indonesia.

Sari, F. M. (2019). Patterns of Teaching-Learning Interaction in the EFL Classroom. TEKNOS ASTIK, 16(2), 41. https://doi.org/10.33365/ts.v16i2.139

Smpn, P. (2015). The Forms Of Classroom Interaction Found In English Classroom At Sma Negeri in Bengkulu (A Comparative Study between Favorite and Un-Favorite Schools in Bengkulu). In Center of Language Innovation Journal of Linguistics and Language Teaching (Vol. 2, Issue 2). 